\title{
VALUE ORIENTATIONS OF PEOPLE LEANING TOWARD DIFFERENT TYPES OF CULTURE
}

\author{
OKSANA RYBAK \\ Faculty of Philosophy, Ivan Franko National University of Lviv \\ Uniwersytetska 1, Lviv, Ukraine \\ E-mail address: rybako@hotmail.com
}

\begin{abstract}
Aim. The aim of the research is to generalize the most topical scientific approaches to value orientations, disclose the importance of value orientations in personality development, and highlight the influence of culture on value orientation development.

Methods. One hundred and eighty Ukrainian participants completed the Milton Rokeach's Test 'Value Orientations' (1973), Vladimir Sopov and Ludmila Karpushyna's Morphology Test of Life Values (2001), Ludmila Pochebut's Test 'Cultural and Value Orientations' (2004), Ivan Diachuk's Test 'Understanding of Moral Values' (2010), Dmitrij Leontiev's Test 'Life Sense Orientations' (2000). Answers to the tests made it possible to divide participants by different types of culture and built out hierarchy of values preferable for them.

Results. The analysis shows that two clusters of examinees leaning toward different types of culture are empirically outlined. Their value orientations and dependence of the established values on the type of culture they lean toward is studied. The research has also indicated that in traditional culture and modern culture there is different hierarchy of values.

Conclusions. Outlining of such types of culture as traditional, modern, and dynamically developing culture enables clarification of special features of culture in general. Division of culture as the system into simpler subsystems, which are characterized by certain features, enables analysis of the very phenomenon of culture in detail. Besides that, in this study the importance of values and value orientations as an integral characteristic of culture is stressed.
\end{abstract}

Key words: values, value orientations, culture, types of culture, traditional culture, modern culture, dynamically developing culture.

\section{PROBLEM STATEMENT}

In transitional periods of society development the problem of values is becoming of primary importance. The Ukrainian society is living through a period of instability, social transformations, certain disorientation and misidentification of an individual. It is logical that this situation affects the process of value reassessment, when an individual as well as society in general rejects old values, without, however, having clearly developed new ones (Pidluzhna, 2009, p. 73-77). 
It is well-known that the system of value orientations reflects a meaningful treatment of social reality by an individual and thus determines motivation for his/her conduct, significantly affecting all the sides of his/her activity. That is a complex social and psychological phenomenon characterizing the direction and content of individual activity, determining the overall person's approach to the world, to the very individual, attaching sense and direction to personal standpoints, conduct, actions. The system of value orientations has a multi-tier structure. At its top are the values related to ideals and life goals of an individual. As an element of personality structure, value orientations characterise internal readiness to performing certain activities for the sake of meeting the needs and fulfilling the interests, indicate the direction of individual's conduct. Since the set of values absorbed by an individual in the course of socialization is 'translated' to him/her by the society itself, the study of the system of value orientations of a personality which grows and develops in a certain culture turns out to be a particularly topical issue. The study of value orientations available in modern society requires clarification of the nature and the mechanisms of the ongoing processes.

\section{ANALYSIS OF THE LATEST STUDIES AND PUBLICATIONS}

In the social and psychological approach the overall methodological basis for analyzing value orientations lies in understanding of the essence of personality as a derivative from societal relations. This direction is developed in the studies of the following psychologists: Ksenija Abulkhanova-Slavska, Boris Ananiev, Boris Kruhlov, Aleksej Leontiev, Boris Lomov, Sergej Rubinstein, Katherina Shorokhova, et al. In the general psychological approach interrelations of value orientations with motivation, self-fulfillment, satisfaction, personal activity are considered (Vladimir Asieyev, Vil Bakirov, Yurij Zabrodin, Abraham Maslow, et al.). It is stressed in the studies of Georgij Ball, Boris Dodonov, Dmitrij Leontiev that values characterise personality direction and are manifested primarily in the activity motives (Hlynianyuk, 2010).

Different researchers $(\mathrm{Hu}, \mathrm{Xu}, \& \mathrm{Mai}, 2017)$ claim social value orientation is a stable personality trait that reflects how people evaluate interdependent outcomes for themselves and others in social environments. Generally, people can be classified into two types: proselfs and prosocials with specific value orientations. The relationship between values and personality traits is more complex than most psychological studies assume, as some personality traits that might be expected to have a strong cognitive component are influenced more by values, while others, vice versa, are weakly associated with values. The influence of values on traits largely occurs on a conscious level, has a decidedly cognitive basis, and may vary in the long term and change its polarity in response to strong confrontations with the social environment, while the strength and polarity of the influence of personality traits on values remains stable over time (Anýžová, 2017). 
Analysing researches of values we can see that scientists (Schwartz, Bilsky, 2010) consider the values within two cross planes: personal and cultural. The values act as the axiom of motivation and implementation of various types of activity as well as reflect general universals. Vitaliy Tomin (2017, p. 59-64) established that the values can act simultaneously as the basis, resource, condition and fact of interaction. At the same time, the coexistence of projections of different cultures' values in the person's mind causes the obstacles in the selection of strategies of their relevant manifestation within the conditions of cross-cultural interaction. The external and internal changes of each interaction party are the result of cross-cultural interaction. To resolve value orientations conflict, people face the issue of the selection of various behavior strategies. The strategies of transformation or compromise promoting the process of personal development and improvement of an individual are considered the most successful behaviour strategies within the cross-cultural interaction.

One of the topical problems of modern psychology is the issue of analysing the connection between culture as a social and psychological phenomenon and mental processes, individual conditions, human conscience, thinking, etc. This issue has been studied by Tatyana Rahozina, Tatyana Stefanenko, Melvill Herskovits, Yan Shchepanskyi, Garry Triandis, Klodd Levi-Stross, Frans Boas, Sergej Tokariev, Rut Benedict, Lurie, Friedrich Nietzsche, Michael Cole, Lucien Levy-Bruhl, Gustav Shpet, Vladimir Iordanskyy, et al (Rahozina, 2011).

Statement of article objectives: to reveal the notion of value orientations, establish interrelation of value orientations of individuals and the type of culture they lean toward. One of the tasks of the article is empirical study of value orientations of individuals leaning toward different types of culture.

\section{LAYOUT OF CORE MATERIAL}

Value orientations make up the core personality structure. Thus, Florence Kluckhohn and Fred Strodtbeck considered personality as a set of value orientations. They determined cultural and value orientations as complex principles grouped in a certain way, which direct the flows of human thinking and activity toward settlement of general human problems. Those orientations are laid down in the period of child socialisation within a cultural tradition.

Value determinants of culture and value determinants of an individual as a member of this culture were considered as identical (Kluckhohn, \& Strodtbeck, 1961).

Specialists in the field of psychology of culture claim that standard canons of psychological culture of personality cannot be studied without referring them to a specific social group which differs primarily by way of living, value orientations, rules and stereotypes of conduct. Thus, Michel Argyle writes that "these characteristics of a social group cause the norms of mind regulation and development. Social and cultural traditions of the society, characteristic of the way of living, the level of socium development, psychological culture of 
an individual are all the phenomena closely interconnected and stipulated by each other. Their isolated development or directed modification are impossible with no due account of those interconnections" (Argyle, 2002).

Ethno-psychologists claim that 'transplantation' of psychological culture from one community to another one, at least with no respective modification and adaptation, is doomed to failure. Aleksandr Asmolov writes: "For instance, wide-spread application of the method of self-regulation propagated in the Buddhist culture and currently popular in some social groups of European countries will hardly be successful and deep, if the principles of individual self-development and self-improvement characteristic of Buddhism are not integrated at the same time, since these principles are in conflict with the components shaping psychological culture of European ethnoses. This fact leads to tension in internal and in interpersonal relations (Asmolov, 1990, pp. 271-272).

The representatives of psychological anthropology are primarily interested in the ways of child socialisation applied by different peoples. Scientists claim that culture is determined by conduct. This conduct is called socio-typical individual conduct by A. G. Asmolov. "That is the conduct that contains typical programs of this culture and regulates activity in situations standard for this community, which makes the individual free from taking his/her individual decisions. Since socio-typical conduct is adjusted to a certain way of living, it fails when an individual gets into a non-standard situation, in particular, into a different culture" (Asmolov, 1990, pp. 271-272).

Value orientations, evaluations, expectations, models can be realised and not realised. They are historically and ethnically pre-determined. Each ethnos has its dominants in this component of psychological culture, for instance: European ethnoses - intellectual development, India, China, Japan - selfregulation improvement, Arabic East - communicative competence, the art of communication.

It should be indicated that there are different opinions of the connection between culture and ethnos. Many researchers consider the borders of culture and ethnos as non-identical. On the one hand, similar elements of culture can be traced with different peoples. On the other hand, each ethnos may include highly divergent elements of culture - Ukrainians live in the Luhansk and Lviv regions, but how different their houses, suits, clothes, and dances are. One could react to this saying that culture is not a set, but a system of somehow interrelated elements. No two different ethnoses can be found with absolutely same cultures.

Tatyana Stefanenko (1999, pp. 19-20) writes that it is also necessary to bear it in mind that in the system of notions accepted in ethnology culture often stands for all the integrity making up this ethnos. In such understanding, culture embraces all the manifestations of social life and activity, with no division into the fields of economy, politics, social relations and culture in the narrow sense of the word. In other words, the term 'culture' stands for the society in general and even a race in general. From now on culture cannot be related to individual human skills only or identified with a certain special field of societal life. 
In scientific literature there exist many approaches to the typology of culture. Let us consider the most important of them. Thus, Margaret Mead (1955) distinguishes between three types of culture, analysing relations between generations and contrasting them with the pace of societal development and the type of family organisation. Thus, the researcher points out post-figurative, configurative, and pre-figurative cultures.

In post-figurative cultures children primarily learn from their predecessors, and the past experience of adults acts as the future of new generations. Such cultures are characterised by a slow flow of any changes. An important feature of post-figurative cultures is the statement that the way of living is unchangeable and remains the same.

There are two key conditions for post-configurative culture preservation - absence of doubts and unawareness. Quite often post-figurative styles of culture are restored after periods of revolts and revolutions directed against them. This frequency points to accessibility of this form of culture to modern individuals, the same as it was accessible for our ancestors thousands of years ago. All the divergences laid down in the monuments of history, in the archives and codes of laws can be reabsorbed by such systems since they are perceived in a non-critical way, are beyond the limits of conscience and are, therefore, not subject to analytical thinking (Mead, \& Wolfenstein, 1955).

Configurative cultures are characterized by the study of children and adults from their peers. Societies where configuration is the only form of cultural transfer are just a few, and no single society is known where only this model would be in existence for several generations. In the society where configuration would be the only cultural transfer model, both old, and young people consider the difference in the forms of conduct of each following generation as compared to the previous one natural. In all configurative cultures people older in age guide, determining the style of configuration, setting the limits of its manifestation in the conduct of young people.

Pre-figurative cultures reflecting modern life presuppose that adults also learn from their children. The modern times are characterized by the combination of cultures and people since their representatives actively communicate within the electronic communicative system. Thus, the younger generation has got joint experience older people have never had and will never have. And also the experience of the older generation will never be repeated in the way of living of young people. M. Mead indicates that cultural transmission takes place not only in the direction from parents to children, but also vice versa from children to parents. A phenomenon is wide-spread when children interpret the present and cultural heritage in their own way and, thus, partially change the attitude of the older generation to traditionally accepted things.

However, in the opinion of I. Kon (1967, p. 35), the experience of the past generations and a certain cultural tradition always stands as the 'reference point' for any innovations introduced by the younger generation.

A well-known researcher of social groups, ethno-psychologist Ludmila Pochebut (2007, p. 165) also dealt with the study of culture and its typology. 
On the basis of a test L. Pochebut (2007, p. 171) developed her classification and distinguished between three types of cultures, viz. traditional, modern, and dynamically developing culture.

Traditional culture is characterized by people's orientation toward the past, compliance with traditions, interest in the history of their country. The representatives of this culture perceive nature as an eternal secret of being they are not striving to uncover. An individual is considered as a person dependent on his/her closest social milieu. Of great importance here are family relations, traditional nature of role relations in the family, religious orientations. Inner human freedom is not allowed in such culture. Permanent strict supervision over human deeds, actions and even thoughts is exercised by the society. The decision-making procedure is a joint one, the result of the decision depends on older people. Human activity is strictly regulated. Individuals are usually remunerated for achievements at work and for creative treatment of their job not immediately, but in a certain time.

Modern culture is characterized by the orientation of people toward the present, toward current events. People try to live in harmony with nature, cherish it, be interested in environmental issues. Human essence is perceived as a rather controversial phenomenon. The values of this culture focus on humans, their rights, calling, development of their abilities, self-fulfillment and selfactualization. Relations between people are normally of a formal nature, they are clearly determined by the status and role in the social system. Friendly relations are established slowly and characterized by depth and dedication. The society strives to regulate human conduct on the basis of morale, ethical norms and rules. In the course of communication people are normally reserved, they try to keep some social distance and keep to role prescriptions. Individual decisions are passed in the process of coordination of mutual needs, interests and plans for the future with a group, family, working collective. Individuals strive to get not material, but moral remuneration (fame, recognition, success) for the results of their activity.

Dynamically developed culture is characterized by people's orientation toward the future, achievements of quick substantial results. People create short-term plans and try to bring them into life as quickly as possible. For people of this culture 'time is money'. Nature is not a mystery. Since life is a problem which needs to be settled quickly and successfully, nature should be subordinated to humans. All its mysteries need to be cleared up, development laws must be established and described. The task of individuals is to guide nature. Human nature is considered to be freedom-loving. Individuality, independence, autonomy from social environment are cultivated. The decision-making process is individual. Individual interests and values are of greatest importance. People are frank, sincere, unaffected in communication, guided toward the equality of role relations, and not hierarchy. Provision of equal opportunities by the society for the sake of development of each individual is considered to be a socially recognized value. Not morale, but legality, impossibility of punishment avoidance and the imminence of material remu- 
neration constitute the basis for social control. Attention of the representatives of the given culture focuses on assignments, work, business. Individuals often frequently martyr themselves for the cause, success, progress, material wellbeing. Successful activity presupposes primarily quick material remuneration.

Generalizing those characteristics of different types of culture, one may point to the following divergences between them (table 1).

Table 1. Divergences between different types of cultures (according to L. H. Pochebut)

\begin{tabular}{|c|c|c|}
\hline Traditional culture & Modern culture & $\begin{array}{l}\text { Dynamically developing } \\
\text { culture }\end{array}$ \\
\hline $\begin{array}{l}\text { Orientation towards the } \\
\text { past }\end{array}$ & $\begin{array}{l}\text { Orientation towards the } \\
\text { present }\end{array}$ & $\begin{array}{l}\text { Orientation towards the } \\
\text { future }\end{array}$ \\
\hline $\begin{array}{l}\text { Compliance with } \\
\text { traditions, interest in the } \\
\text { history of own country }\end{array}$ & $\begin{array}{l}\text { Values of this culture } \\
\text { focus on individuals, their } \\
\text { rights, development of their } \\
\text { abilities, self-fulfillment and } \\
\text { self-actualisation }\end{array}$ & $\begin{array}{l}\text { Equal opportunities for } \\
\text { the development of each } \\
\text { individual are considered } \\
\text { to be a socially recognised } \\
\text { values. Individual } \\
\text { interests and values. }\end{array}$ \\
\hline $\begin{array}{l}\text { Great importance } \\
\text { of the closest social } \\
\text { environment }\end{array}$ & $\begin{array}{l}\text { Relations between people } \\
\text { normally are of a formal } \\
\text { nature }\end{array}$ & \\
\hline $\begin{array}{l}\text { There is permanent } \\
\text { supervision over } \\
\text { human deeds, actions } \\
\text { and even thoughts by the } \\
\text { society }\end{array}$ & $\begin{array}{l}\text { The society strives to regulate } \\
\text { human conduct on the basis } \\
\text { of morale, ethical norms and } \\
\text { rules }\end{array}$ & $\begin{array}{l}\text { Morale, and not legality } \\
\text { constitute the basis of } \\
\text { social control }\end{array}$ \\
\hline $\begin{array}{l}\text { Traditional nature of role } \\
\text { relations in the family }\end{array}$ & $\begin{array}{l}\text { Relations between people are } \\
\text { normally of a formal nature, } \\
\text { they are clearly determined } \\
\text { by the status and role in the } \\
\text { social system }\end{array}$ & $\begin{array}{l}\text { Openness, sincerity, } \\
\text { directness in } \\
\text { communication, } \\
\text { orientation towards the } \\
\text { equality of role relations, } \\
\text { but not towards hierarchy }\end{array}$ \\
\hline $\begin{array}{l}\text { Joint decision-making } \\
\text { procedure }\end{array}$ & $\begin{array}{l}\text { Individual decisions are } \\
\text { passed in the course of } \\
\text { coordination of mutual } \\
\text { needs, interests and plans } \\
\text { with a group, family }\end{array}$ & $\begin{array}{l}\text { Decision-making process } \\
\text { takes place individually }\end{array}$ \\
\hline
\end{tabular}

A. V. Halychanska's (2011, p. 19) studies show that in our society there dominates modern and traditional type of culture, while dynamically developing culture manifests itself as a real cultural environment to the smallest extent. Though most respondents have shown their willingness to live in a traditional culture. Such situation can be accounted for by leaning toward stability and sustainability, confidence about tomorrow. 


\section{EMPIRICAL STUDY}

We have applied the following methodologies in the empirical study of value orientations of people leaning toward different types of cultures: Test 'Value Orientations' by Milton Rokeach (1973); morphology test of life values by Vladimir Sopov and Ludmila Karpushyna, (2001), test 'Cultural and Value Orientations' by Ludmila Pochebut (2007), test 'Understanding of Moral Values' by Ivan Diachuk (2010) as well as test 'Life Sense Orientations' by Dmitrij Leontiev (2000).

Cluster, comparative, and correlation analyses have been used to process primary results (in program STATISTICA 10.0). The group of examinees was made up of 80 people, viz. students of the Ivan Franko National University of Lviv aged $22-24$.

For a more complete clarification of the essence of values we have made cluster analysis, which has enabled us to point out two groups of examinees leaning toward different types of culture. The scales of leaning toward a certain type of culture have been taken as the basis, where examinees leaning to TC (traditional culture) formed the first cluster, while examinees leaning to MC (modern culture) and DDC (dynamically developing culture) - the second cluster.

The first cluster included 37 examinees (correctness of clustering - 100\%), the second -43 persons (correctness of clustering - 100\%), Thus, the first cluster included $46 \%$ of examinees, while the second cluster $-54 \%$ of examinees.

Figure 1. Graphic depiction of direct relations between leaning to TC and value orientations

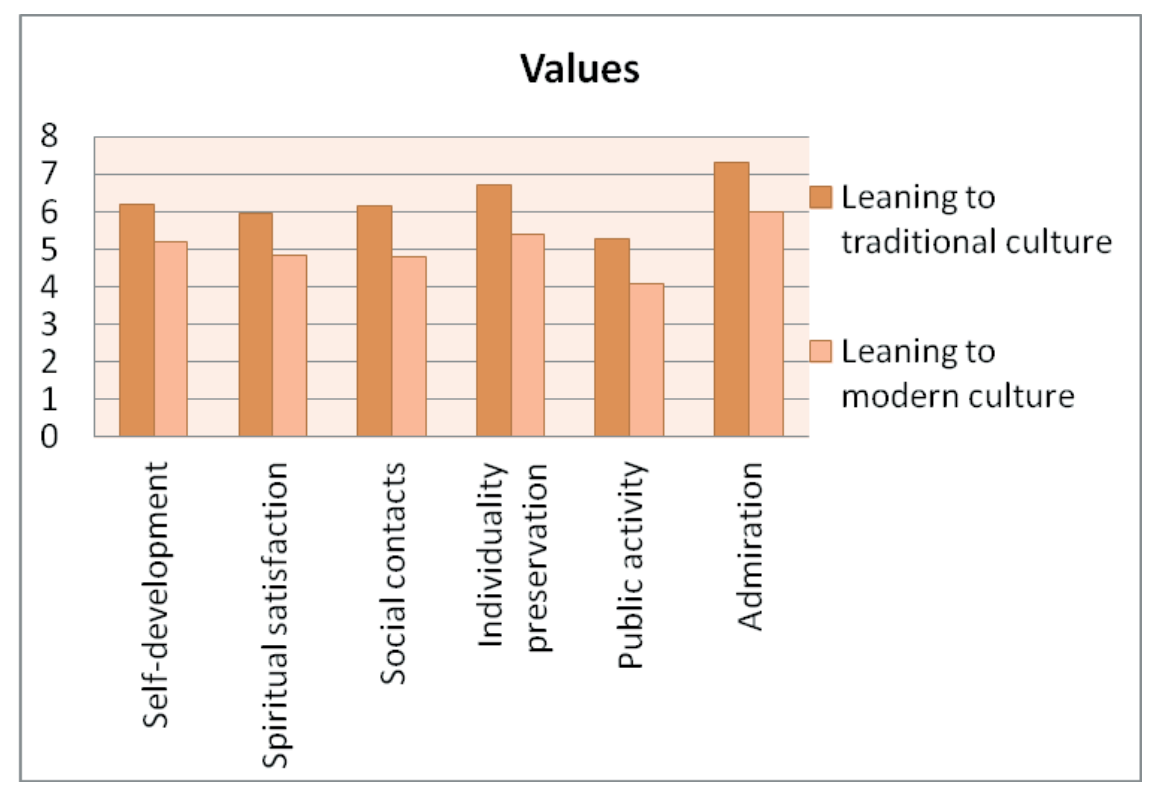


Comparative analysis according to Students' $\mathrm{t}$-criterion pointed to significant differences between these two groups. As it can be seen from the figure (fig. 1), examinees from the first cluster show a higher figure for such life values as selfdevelopment (cognition of individual peculiarities, permanent development of one's abilities and other personal characteristics), spiritual satisfaction (compliance with moral and ethical principles, domination of spiritual needs over material ones), social contacts (establishment of favourable relations in different fields of social interaction, expansion of interpersonal contacts, fulfillment of one's social role), preservation of individuality (domination of own opinions, views, beliefs over generally accepted ones, protection of their unique nature and independence), striving to deal with public activity and bring their admirations into life, that is all those values are more important for examinees who lean toward TC. Of interest is the fact that preservation of individuality is more important for those leaning toward TC than to MC.

According to M. Rokeach's methodology, ranking of values was used, therefore smaller result proves greater importance of values for this cluster. As far as terminal values are concerned, it has been traced that examinees leaning to MC attach more importance to availability of good and faithful friends (it is $\mathrm{MC}$ that is characterized by the fact that friendly relations are established slowly and are deep and dedicated). While those leaning to TC value more productive life, that is the best use of their opportunities, effort and abilities for the sake of society and social environment.

As far as instrumental values are concerned, those leaning to MC attach special importance to education, that is the width of own knowledge and high general culture, as well as rationalism, that is the ability to apply realistic and logical thinking, take well-grounded, rational decisions.

Thus, cluster analysis has enabled clarification of the specificity of values of examinees leaning toward different types of culture.

Taking into account the hierarchy of values for the two clusters, the following differences should be pointed out. Health, love, life wisdom, self-confidence, active efficient life - they have all turned out to be most important terminal values for people leaning toward traditional culture. In their turn, for people leaning toward modern culture, the following hierarchy has been built: love, health, self-confidence, development, happy family life. Thus, in traditional culture the first place goes to the value of health, while in modern culture - love. According to Erik Erikson's theory, it is at the young age that people settle the issues of love (Erikson, 2006, p. 178). We see this value in the first place in people leaning toward modern culture. In traditional culture the first place goes to the global value of health, while love takes already the second place. The third place goes to life wisdom, which is transferred from generation to generation and points to the importance of interrelations between generations, unlike modern culture, where this interrelation is not critical, the focus is on individuality and personality development. Thus, in modern culture the third and fourth places by importance go to self-confidence and self-development respectively. This is accounted for by the fact that in modern culture people rely on their own forces, 
on their own abilities. One more special feature of persons leaning toward modern culture is attachment of great importance to happy family life, while with people leaning toward traditional culture active efficient life appears to be in the fifth place of the value matrix. This situation is accounted for by the fact that active efficient life presupposes the best effort of people taken in favour of general welfare, in favour of the society where the individual stays.

In its turn, in the course of the study as most important instrumental values for persons leaning toward traditional culture there have been outlined integrity, vivacity, independence, responsibility, and level of education. While with persons leaning toward modern culture, level of education has taken the first place among instrumental values. In modern culture the level of education is considered as the way of achieving independence, financial independence. Unlike persons belonging to modern culture, persons leaning toward traditional culture attach primary importance to such instrumental value as integrity which is important for the well-being of not just a separate individual but the whole society. Vivacity and independence act as equally important for both clusters. Self-control takes the fifth important place for people leaning toward modern culture since they think that everything is in their hands, they can rule their life, one just needs to learn to guide oneself, that is to exercise self-control. While for people leaning toward traditional culture an important value here is responsibility, primarily responsibility to the society for their deeds, achievements.

Correlation analysis of the value study results for people leaning toward different types of cultures has proven the following interrelations between scales (with the level of importance $\mathrm{p}<0.05$ and Rкp. $=0.39$ ):

Direct correlation between leaning toward TC and the following scales: selfdevelopment (0.24), spiritual satisfaction (0.24), social contacts (0.29), material status (0.26), individuality preservation (0.28) (fig. 2).

Figure 2. Graphic depiction of direct relations between leaning to TC and value orientations

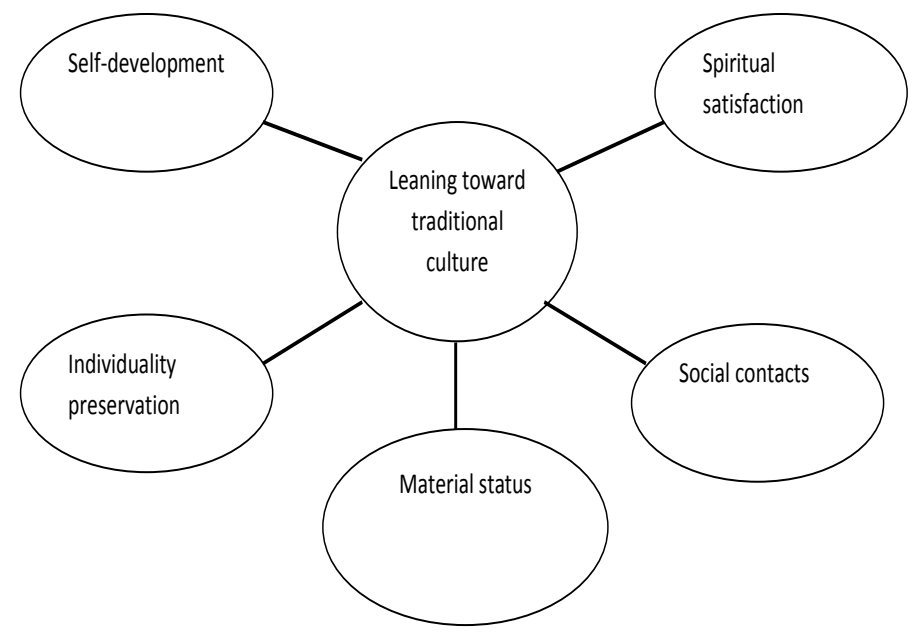


Reverse correlation between leaning toward TC and the scale 'Availability of good and faithful friends' can be traced (0.25). Direct relation of leaning toward TC and the scale 'Productive life' has been established (-0.28). Due to ranking interpretation is made from the reverse.

Figure 3. Graphic depiction of direct and reverse relations between leaning to TC and value orientations

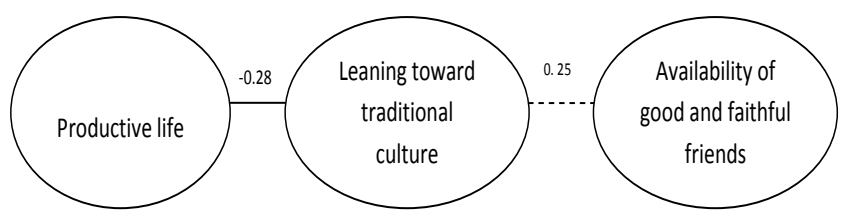

People leaning toward traditional culture attach a considerable importance to productive life, that is the most complete use of their opportunities, effort, and abilities for the sake of society and its members. While availability of good and faithful friends is not an important value for people leaning toward traditional culture, which fact can be accounted for by availability of strong relations within the family and extended family.

With people leaning toward $\mathrm{MC}$ reverse correlation can be traced with the following scales: spiritual satisfaction (0.22), individuality preservation (0.26) (fig. 4).

Figure 4. Graphic depiction of reverse relations between leaning to $\mathrm{MC}$ and value orientations.

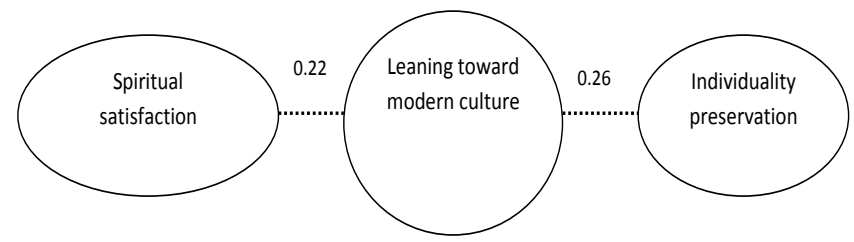

As can be seen, people leaning toward modern culture attach a smaller importance to spiritual satisfaction, which fact is accounted for by the perception of modern reality as a dynamic process. Also, these people do not attach significant importance to individuality preservation. Such situation is accounted for by the fact that the value in question is fulfilled, people do not feel any threat to the preservation of their own individuality, they can freely show it.

\section{CONCLUSIONS}

Thus, according to the results of the study the relation between the personality's value orientations and the type of culture (s)he leans toward has been 
confirmed. The performed empirical study has enabled determination of the following special features:

Individuality preservation is more important for the group of examinees leaning toward traditional culture (hereinafter referred to as TC) than for the group of examinees leaning toward modern culture (hereinafter referred to as $\mathrm{MC}$ ). This fact can be accounted for by the fact that traditional culture is characterized by a smaller possibility of ensuring protection of unique nature and independence of an individual, that is preservation of his/her individuality, which is why examinees stress this value.

Examinees leaning to $\mathrm{MC}$ attach a greater importance to availability of good and faithful friends. Modern type of culture is characterized by the fact that friendly relations are established slowly and are characterized by their in-depth nature and dedication. While those leaning toward TC value more productive life, that is the best use of their opportunities, effort, and abilities for the sake of society and social milieu.

Examinees leaning toward MC attach a greater importance than those leaning to TC to education, that is the width of own knowledge and high general culture, as well as rationalism, that is ability to apply realistic and logical thinking, take well-grounded, rational decisions.

Analyzing different approaches to the typology of culture, we can see that culture consists of many subsystems, and components of those subsystems closely interact with one another. Each component acts as the necessary condition for the functioning of culture. Application of methods do not violate fundamental mutual relations and enable outlining of simpler blocks and also enable description of important features inside those blocks. Thus, outlining of the types of culture is the methodological way to analyse and study them. Outlining of such types of culture as traditional, modern, and dynamically developing culture enables clarification of special features of culture in general. Division of culture as the system into simpler subsystems, which are characterized by certain features, enables analysis of the very phenomenon of culture in detail. Besides that, in this study the importance of values and value orientations as an integral characteristic of culture is stressed.

\section{RESEARCH PROSPECTS}

The prospects of study of the given range of problems are, in our opinion, as follows: development of our own typology of culture, that would be actual for present society, as well as questionnaire for types of culture determination.

\section{REFERENCES}

1. Anýžová, P. (2017). The Social-Psychological Context of Human Values: The Reciprocal Relationship between Personality Traits and Value Orientations. Sociologický časopis/Czech Sociological Review, 53(3), 393-426. 
2. Argyle, M. (2002). The Psychology of Happiness. London: Routledge.

3. Asmolov, A.G. (1990). Психология личности [Psychology of Individual]. Moscow: Moscow University Publishing House.

4. Danyliuk, I.V. (2013). Маргарет Мід як фундатор наукового напряму “Культура i особистість" [Margaret Mead as the Founder of the Scientific Direction "Culture and Personality"]. Psychology and Personality, 2(4), 29-42.

5. Halychanska, A.V. (2011). Родинна традиція як умова запобігання міжпоколінних конфліктів y niдлітків в сім'ї [Family Tradition as a Condition for Preventing Inter-Generational Conflicts with Teenagers in the Family]. PhD thesis in Psychology. Kyiv.

6. Hlynianyuk, N.V. (2010). Психолого-педагогічні умови формування иіннісних орієнтацій сучасної студентської молоді [Psychological and Pedagogical Conditions of Developing Value Orientations in Contemporary Student Youth]. Retrieved from http://tme.umo.edu. ua/docs/Dod/3_2010/Glinaniyk.pdf

7. Erikson, Е. (2006). Идентичность: юность и кризис [Identity: Youth and Crisis]. Moscow: Flinta.

8. Kluckhohn, F. \& Strodtbeck, R. (1961). Variations in value orientations. Evanston, IL: Row Peterson.

9. Kon, I. (1967). Социология личности [Sociology of Personality]. Moscow: Политиздат.

10. Mead, M., \& Wolfenstein, M. (1955). Childhood in Contemporary Cultures. Chicago: University of Chicago Press.

11. Pidluzhna, О.Р. (2009). Система цінностей як основа формування культури споживання [The System of Values as the Basis for Consumption Culture Development]. Scientific messages, 96, 73-77.

12. Rahozina, T. Е. (2011). Культура: исторические судьбы термина и понятия [Culture: Historical Fates and Notions]. Gilea, 55(12). 374-379.

13. Stefanenko, T.G. (1999). Етнопсихология [Ethnopsychology]. Moscow: Institute of Psychology RAN.

14. Tomin, V. (2017). Ценности и ценностные ориентации как основа кросскультурного взаимодействия студентов [The Values and Value Orientations as the Basis of Cross-Cultural Interaction of the Students]. Вектор науки ТГУ, 2, 59-64.

15. $\mathrm{Hu}, \mathrm{X} ., \mathrm{Xu}, \mathrm{Z} .$, \& Mai, X. (2017). Social value orientation modulates the processing of outcome evaluation involving others. Social Cognitive and Affective Neuroscience, 12(11), 1730-1739. 